Research Article

\title{
Prevalence of Delirium and Its Clinical Outcome in Adult Filipino Patients Admitted in The Intensive Care Unit
}

\author{
Abram P Tanuatmadja*, Jacqueline R Vea** \\ * Department of Internal Medicine Faculty of Medicine Maranatha Christian University \\ Jl. Prof. drg. Suria Sumantri MPH No.65 Bandung 40164 Jawa Barat Indonesia \\ **University of the Philippines - Philippine \\ General Hospital, Department of ClinicalEpidemiology \\ Manila Taft Avenue, Manila Philippines 100 \\ Email:abram.pratama@gmail.com
}

\begin{abstract}
Delirium is common in the ICU setting and is associated with increased morbidity, manpower requirement, and costs. This study aims to investigate the prevalence of delirium and its outcome in terms of 14-days mortality and length of ICU stay in ICU patients. The study was done at a 150-bed tertiary teaching hospital, located in Quezon City, Metro Manila, February to September 2016. This is a prospective studyinvolving 136 adults. Screening for delirium was done within 24 hours of ICU admission using both CAM-ICU scoring method and DSM-IV-TR criteria for delirium. Delirium prevalence was found to be $5.15 \%$. The average age was higher in the subjects positive for delirium $(70.14 \pm 21.15$ years versus $60.43 \pm 16.10$ years, $p=0.1286)$. At the time of ICU admission, $11.54 \%$ of sedated patients were positive for delirium compared to $3.64 \%$ of non-sedated patients, $p=0.1513$;OR 3.457. Delirium was associated with higher 14 days mortality (OR 16.8, $p=0.0212$ ). Subjects positive for delirium had 2.74 longer days average ICU stay compared to the other group, with $p=0.026$. We concluded delirium was associated with higher 14-days mortality and longer ICU stay.
\end{abstract}

Keywords : delirium, prevalence, Intensive Care Unit 


\title{
Prevalensi dan Keluaran Klinis Delirium pada Pasien Filipino Dewasa di Ruang Rawat Intensif
}

\author{
Abram P Tanuatmadja*, Jacqueline R Vea ** \\ *Bagian Ilmu Penyakit Dalam Fakultas Kedokteran Universitas Kristen Maranatha \\ J1. Prof.Drg.Surya Sumantri, MPH No 65 Bandung 40164 Indonesia \\ **University of the Philippines - Philippine \\ General Hospital, Department of Clinical Epidemiology \\ Manila Taft Avenue, Manila Philippines 100 \\ Email: abram.pratama@gmail.com
}

\begin{abstract}
Abstrak
Delirium adalah suatu kondisi yang umum ditemui di ICU, dan berhubungan dengan peningkatan morbiditas, kebutuhan tenaga kesehatan, dan biaya. Penelitian ini bertujuan untuk mengetahui prevalensi dan clinical outcome dari delirium, yakni angka kematian 14-hari dan lama tinggal di ICU, pada pasien ICU. Penelitian ini dilakukan di sebuah rumah sakit pendidikan rujukan tersier (PPK3), yang berlokasi di Quezon City, Metro Manila, Filipina, selama periode Februari-September 2016. Penelitian ini bersifat prospektif, melibatkan 136 subjek penelitian yaitu pasien dewasa yang masuk ICU. Skrining delirium dilakukan dalam 24 jam pertama menggunakan skor CAM-ICU dan kriteria DSM-IV-TR untuk delirium. Pada penelitian ini, ditemukan prevalensi delirium sebesar 5,15\%. Rerata usia lebih tinggi pada kelompok positif delirium $(70,14 \pm 21,15$ vs. $60,43 \pm 16,10$ tahun, $p=0,1286)$. Saat masuk ke ICU, $11,54 \%$ dari pasien yang disedasi didiagnosis positif delirium, dibandingkan dengan $3,64 \%$ pada pasien yang tidak disedasi $(\mathrm{p}=0,1513$; OR 3,457$)$. Delirium berhubungan dengan angka mortalitas 14 hari $(O R 16,8, \mathrm{p}=0,0212)$. Kelompok positif delirium tinggal rata-rata 2,74 hari lebih lama di ICU dibandingkan kelompok negatif delirium $(\mathrm{p}=0,026)$. Penelitian ini menyimpulkan delirium berhubungan dengan angka mortalitas 14-hari yang lebih tinggi dan durasi rawat di ICU yang lebih lama.
\end{abstract}

Kata kunci: delirium, prevalensi, Intensive Care Unit 


\section{Research Article}

\section{Introduction}

Delirium is defined by the American Psychiatric Association's (APA) Diagnostic and Statistical Manual of Mental Disorders (DSM)-IV-TR as a disturbance of consciousness and a change in cognition that develop over a short period of time. ${ }^{1,2}$ Development of delirium in the hospital is associated with increased morbidity, closer nursing surveillance, higher hospital costs per day, longer hospitalizations, and increased rates of nursing home placement upon discharge $^{3}$, and it has also been previously reported as an independent predictor of mortality ${ }^{4}$, hence its importance in the ICU setting. ${ }^{5}$ The misnomer 'ICU psychosis' has now been abandoned and efforts have been made to improve screening and diagnosis of delirium. ${ }^{6}$ One of the bedside clinical assessment tools available for that purpose is Confusion Assessment Method for the ICU (CAM-ICU) Score. Worldwide, it is the best validated and most frequently used delirium assessment instrument in ICU patients by non-psychiatrists. ${ }^{3,46}$ However, to date, delirium screening is not yet routinely done locally in our ICU setting. Most of the report of "ICU psychosis" cases are undocumented, or only verbally endorsed from duty teams.

This study aims to determine the prevalence of delirium using the CAM-ICU score and DSM-IV-TR criteria as gold standard and correlate the presence of delirium with 14-days mortality and length of ICU stay in the adult ICU patients at the De Los Santos Medical Center during the time period of February 1, 2016 to September 7, 2016. By studying the delirium prevalence and its impact on morbidity and mortality, measured by 14-days mortality and length of ICU stay, we hope to improve the rate of early identification in high-risk patients, which in turn may improve patient outcome and overall morbidity and mortality rates in our institution's ICU.

\section{Methods}

This is a prospective study done in adult Filipino patients admitted in ICU of a 150-bed tertiary teaching hospital, located in Quezon City, M.M, during the time period of February 1, 2016 to September 7, 2016. De Los Santos Medical Center Department of Internal Medicine Research Committee approved this study, and none of the authors had any conflict of interests to report.All adult ( $\geq 18$ years of age) in-patients of DLSMC, admitted to ICU during the period of February 1, 2016 to September 7, 2016, whether transferred from the ward or direct-to-ICU from ER or transferred from another institution were included, with the exclusion criteria as follows: 1. Patients already admitted in the ICU prior to February 1, 2016 or not yet discharged or expired at September 7, 2016; 2. Patients for whom required diagnostic tests for CAM-ICU scoring was not done or not able to be done (i.e., because of a waiver, DNR, financial constraints, etc.); 3. Patients who expired, discharged against medical advice, or transferred to 


\section{Research Article}

other hospital before assessment could be done within the first 24 hours of admission; 4 . Patients who had stroke (ischemic or hemorrhagic) or head trauma or a neurologic condition (such as Dementia, Schizophrenia, or late-stage Parkinson's Disease), with impairment resulting in a condition causing him/her to be unable to communicate, or who came in with Glasgow Coma Scale of 7 or less and stayed so within the first 24 hours of admission; 5. Patients who were hearing impaired or unable to speak or understand English; 6. Patients who had been previously enrolled (transferred back to ICU after previously transferred out of ICU).

Screening for delirium was done within 24 hours of ICU admission for all ICU patients, using both CAM-ICU scoring method and DSM-IV-TR criteria for delirium, by a resident physician in Internal Medicine trained in both methods, and verified by an Internist of Neuropsychiatry subspecialty. Scores were collated if they fulfilled the criteria. Demographic profile and medical diagnosis were also collected. Outcomes analyzed were 14-days mortality and Length of ICU stay. Baseline patient characteristics were evaluated along with sedation profile, if available. Results were then statistically analyzed using descriptive statistics, Chisquare test, Fisher's exact test, and Wilcoxon two-sample t-test depending on the variables, using SAS 9.2 software.

\section{Results}

A total of 190 patients were admitted in DLSMC ICU during the study period. There were 136 patients included in the final analysis (Figure 1), with 54 patients excluded, eleven of which were expired, 32 with GCS equal to or less than 7 for at least 24 hours, 9 diagnosed with dementia or late-stage Parkinson, and 2 were schizophrenic.

190 adult (>18 years of age) in-patients of DLSMC, admitted to ICU

during the period of February 1, 2016 to September 30, 2016

54 Excluded:

- 11 Expired, discharged against medical advice, or transferred to other hospital before assessment could be done within the first 24 hours of admission

- $\quad 32$ still with GCS $\leq 7$ for $\geq 24 h$

- $9(+)$ for Dementia and/or late-stage Parkinson

- $2(+)$ for Schizophrenia

136 Enrolled and included in Final Analysis

Figure 1 Flow of Patients in the Study 


\section{Research Article}

The overall characteristics of patients from the final analysis pool is included in Table 1.

Table 1 Baseline Characteristics of the Patients

\begin{tabular}{|c|c|c|c|}
\hline & $\begin{array}{l}\text { Positive } \\
\text { for Delirium } \\
(n=7)\end{array}$ & $\begin{array}{l}\text { Negative } \\
\text { for Delirium } \\
(n=129)\end{array}$ & p-value \\
\hline Age in years, mean (SD) & $70.14 \pm 21.15$ & $60.43 \pm 16.10$ & 0.1286 \\
\hline \multicolumn{4}{|l|}{ Sex, total $(\%)$} \\
\hline Male & $3(42.86 \%)$ & $84(65.12 \%)$ & 0.2517 \\
\hline Female & $4(57.14 \%)$ & $45(34.88 \%)$ & \\
\hline Glasgow Coma Scale Total, mean (SD) & $10.71 \pm 0.76$ & $14.64 \pm 1.10$ & $<0.0001$ \\
\hline \multicolumn{4}{|l|}{ ICU admission cause } \\
\hline Medical, total (\%) & $5(71.43 \%)$ & $75(58.14 \%)$ & 0.6996 \\
\hline Surgical, total (\%) & $2(28.57 \%)$ & $13(10.08 \%)$ & 0.1724 \\
\hline Trauma, total $(\%)$ & 0 & $5(3.88 \%)$ & 1 \\
\hline Neurologic/Neurosurgical, total (\%) & 0 & $36(27.91 \%)$ & 0.1891 \\
\hline \multicolumn{4}{|l|}{ ICU admission diagnosis (Top 5) } \\
\hline $\mathrm{ACS}$ & $2(28.57 \%)$ & $35(27.13 \%)$ & 0.1835 \\
\hline CVD & 0 & $30(23.26 \%)$ & \\
\hline Sepsis & $1(14.29 \%)$ & $18(13.95 \%)$ & \\
\hline Post Op & $1(14.29 \%)$ & $12(9.30 \%)$ & \\
\hline Cardiac Dysrhythmia & 0 & $6(4.65 \%)$ & \\
\hline Others & $3(42.87 \%)$ & $32(24.96 \%)$ & \\
\hline Not Sedated, total (\%) & $4(57.14 \%)$ & $106(82.17 \%)$ & 0.1513 \\
\hline Sedated, Not Post Op, total (\%) & $1(14.29 \%)$ & $7(5.43 \%)$ & \\
\hline Sedated, Post Op, total (\%) & $2(28.57 \%)$ & $16(12.4 \%)$ & \\
\hline
\end{tabular}

From the 136 subjects included in the final analysis, the prevalence of delirium was $5.15 \%$, with 7 patients who were positive for delirium, and 129 negative for delirium. The average age was higher in the patients with delirium $(70.14+21.15$ vs $60.43+16.10$, $\mathrm{p}=0.1286$ ), with no significant difference in prevalence between male and female subjects. Average Glasgow Coma Scale (GCS) score is significantly lower in the subjects with delirium $(10.71+0.76)$ versus patients without delirium $(14.64+1.10)(\mathrm{p}<0.0001) .71 .43 \%$ ( 5 cases $)$ of the delirium-positive subjects were admitted due to medical cause, and $28.57 \%$ ( 2 cases) due to surgical cause. ICU admission causes were classified using primary PhilHealth (Philippines' Universal healthcare Coverage provider, equivalent to Indonesia's BPJS) CBG diagnosis grouping as written by the main attending physician for each patient. 
Table 2 Comparison of 14-days Mortality in Subjects Positive for Delirium and Negative for Delirium

\begin{tabular}{ccccc}
\hline & $\begin{array}{c}\text { Positive for } \\
\text { Delirium }\end{array}$ & $\begin{array}{c}\text { Negative for } \\
\text { Delirium }\end{array}$ & Total & p value \\
\hline $\begin{array}{c}(+) \text { mortality } \\
\text { within 14 days of } \\
\text { ICU admission }\end{array}$ & $2(28.57 \%)$ & $3(2.33 \%)$ & 5 & 0.0212 \\
\cline { 1 - 3 } $\begin{array}{c}(-) \text { mortality } \\
\text { within 14 days of } \\
\text { ICU admission }\end{array}$ & $5(71.43 \%)$ & $126(97.67 \%)$ & 130 & $\begin{array}{c}\text { (Fisher's exact } \\
\text { test) }\end{array}$ \\
\hline Total & & & 136 & \\
\hline
\end{tabular}

In this study, it was shown that 2 out of $7(28.57 \%)$ patients positive for delirium expired within 14 days of ICU admission ( $\mathrm{p}=0.0212)$ compared to 3 out of $129(2.33 \%)$ patients negative for delirium, with Odds ratio of 16.8 .

Table 3 Comparison of Length of ICU stay in Subjects Positive for Delirium and Negative for Delirium

\begin{tabular}{lccc}
\hline & $\begin{array}{c}\text { Positive for } \\
\text { Delirium }\end{array}$ & $\begin{array}{c}\text { Negative for } \\
\text { Delirium }\end{array}$ & P value \\
\hline $\begin{array}{l}\text { No. of patient } \\
\text { Length of ICU stay in days: } \\
\text { Mean } \\
\text { Median }\end{array}$ & 7 & 129 & 0.026 \\
& 5.43 & 2.69 & $\begin{array}{c}\text { (Wilcoxon's two- } \\
\text { sample test) }\end{array}$ \\
\hline
\end{tabular}

This table showed that subjects positive for delirium were staying for an average of 5.43 ICU days ( $201.85 \%$ or 2.74 days longer, $\mathrm{p}=0.026)$ compared to 2.69 days for patients negative for delirium.

On further analysis, based on ICU admission diagnosis/case type, in the medical cases subgroup, there were 3 out of 5 subjects positive for delirium who expired within 14 days of ICU admission $(60.00 \%)$, in contrast to 4 out of 65 subjects negative for delirium $(4.00 \%)$ $(\mathrm{p}=0.0023)$. There was no mortality within 14 days for surgical, trauma, and neurosurgical cases. 
Table 4 Comparison of 14-days Mortality in Subjects Positive for Delirium and Negative for Delirium, by case type

\begin{tabular}{rccc}
\hline & $\begin{array}{c}\text { Positive for } \\
\text { Delirium }\end{array}$ & $\begin{array}{c}\text { Negative for } \\
\text { Delirium }\end{array}$ & p value \\
\hline $\begin{array}{r}\text { No. of patient (Medical) } \\
\text { No. of mortality within 14 days } \\
\text { (Medical) (\%) }\end{array}$ & $\begin{array}{c}5 \\
(60.00 \%)\end{array}$ & $3(4.00 \%)$ & $\begin{array}{c}0.0023 \\
\text { (Fisher's exact } \\
\text { test) }\end{array}$ \\
\hline $\begin{array}{r}\text { No. of patient (Surgical) } \\
\text { No. of mortality within 14 days } \\
\text { (Surgical) (\%) }\end{array}$ & 2 & 13 & N/A \\
\hline $\begin{array}{r}\text { No. of patient (Trauma) } \\
\text { No. of mortality within 14 days } \\
\text { (Trauma) (\%) }\end{array}$ & 0 & 0 & 5 \\
\hline $\begin{array}{r}\text { No. of patient (Neurosurgical) } \\
\text { No. of mortality within 14 days } \\
\text { (Neurosurgical) (\%) }\end{array}$ & & 0 & \\
\hline
\end{tabular}

Table 5 Comparison of Length of ICU stay in Subjects Positive for Delirium and Negative for Delirium, by case type

\begin{tabular}{|c|c|c|c|}
\hline & $\begin{array}{l}\text { Positive for } \\
\text { Delirium }\end{array}$ & $\begin{array}{l}\text { Negative for } \\
\text { Delirium }\end{array}$ & $\mathrm{p}$ value \\
\hline No. of patient (Medical) & 5 & 75 & \multirow{4}{*}{$\begin{array}{c}0.1329 \\
\text { (Wilcoxon's two- } \\
\text { sample test) }\end{array}$} \\
\hline Length of ICU stay in days: & & & \\
\hline Mean & 5.8 & 2.52 & \\
\hline Median & 4 & 2 & \\
\hline No. of patient (Surgical) & 2 & 13 & \multirow{4}{*}{$\begin{array}{c}0.0627 \\
\text { (Wilcoxon's two- } \\
\text { sample test) }\end{array}$} \\
\hline Length of ICU stay in days: & & & \\
\hline Mean & 4.5 & 2.69 & \\
\hline Median & 4.5 & 2 & \\
\hline No. of patient (Trauma) & & 5 & \\
\hline Length of ICU stay in days: & & & \\
\hline Mean & & 1.8 & \\
\hline Median & & 2 & \\
\hline No. of patient (Neurosurgical) & & 36 & \\
\hline Length of ICU stay in days: & & & \\
\hline Mean & & 3.3 & \\
\hline Median & & 3 & \\
\hline
\end{tabular}

This table showed that delirium was also associated with longer ICU stay for both medical and surgical patients albeit with no significant differences, with medical patients positive for delirium staying for an average of 5.8 ICU days $(230.15 \%$ or 3.28 days longer, $\mathrm{p}=0.1329$ ) compared to 2.52 days for patients negative for delirium, and for surgical patients, 4.5 vs 2.69 ICU days $(167.28 \%$ or 1.81 days longer, $\mathrm{p}=0.0627)$ respectively. 


\section{Research Article}

\section{Discussion}

Delirium prevalence was shown to be $5.15 \%$ in this study. To date, all prior studies were done in different centers in other countries, while on the other hand, there was no study done yet as of now in the local setting. The difference of approach in the management of intensive care patients between these centers/countries may explain the relatively low delirium prevalence in our local setting compared to other countries. Another possible explanation was the fact that the local ICU setting at the time of study incorporated not only ICU cases, but also intermediate-care and high-care patients.

From the baseline patient characteristics, it was noted that the presence of delirium is associated with baseline Glasgow Coma Scale, with the average GCS lower in the subjects positive for delirium $(10.71 \pm 0.76)$ versus subjects negative for delirium $(14.64 \pm 1.10)$ $(\mathrm{p}<0.0001)$. This might be related to the prognosis of the patients positive for delirium.

Previous studies have shown that older age is one of the risk factors associated with delirium in the ICU. ${ }^{5,8,9}$ Our study shown that average age was higher in the subjects positive for delirium $(70.14 \pm 21.15$ years $)$, however it was not statistically significant $(p=0.1286)$ compared to subjects negative for delirium $(60.43 \pm 16.10$ years $)$ despite the very visible difference of roughly 10 years of age between the two groups. There is no predominance of any single primary diagnosis in the subjects positive for delirium, in line with previous studies done in the ICU setting in different centers. ${ }^{4,5,10}$

At the time of ICU admission, 3 out of 23 (11.54\%) of sedated patients were positive for delirium and 4 out of 106 (3.64\%) of non-sedated patients were positive for delirium, albeit statistically not significant $(\mathrm{p}=0.1513)$. However, it is worth noting that the odds ratio was 3.457. Prior studies have shown that sedation is associated with a higher risk of developing delirium. ${ }^{1,3,8}$

Delirium was associated with higher 14 days mortality in adult patients in our local ICU with 2 out of 7 (28.57\%) of subjects positive for delirium expired within 14 days of ICU admission in this study, with statistically significant difference $(\mathrm{p}=0.0212)$ compared to 3 out of $129(2.33 \%)$ for the subjects negative for delirium, with Odds ratio of 16.8. On further analysis by case type, in the medical cases subgroup, delirium was associated with 14 days mortality, with 3 out of 5 subjects $(60.00 \%)$ positive for delirium expired within 14 days of ICU admission, in contrast to 3 out of $75(4.00 \%)$ for subjects negative for delirium ( $\mathrm{p}=0.0023)$. This is consistent with prior studies, where delirium was associated with higher mortality. ${ }^{1-10}$ There was lack of data for the surgical, trauma, and neurology/neurosurgical cases to determine whether delirium is associated with mortality in these subgroups. 


\section{Research Article}

Average ICU stay was longer in subjects positive for delirium, with 2.74 longer days average ICU stay, statistically significant at $\mathrm{p}=0.026$. This also supports prior studies ${ }^{3,4,6,8,9}$; On further analysis by case type, average ICU stay for medical patients positive for delirium was 3.28 days longer $(\mathrm{p}=0.1329)$ compared to 2.52 days for patients negative for delirium, while for surgical patients, it was 4.5 vs 2.69 ICU days ( 1.81 days longer, $\mathrm{p}=0.0627)$. There was lack of data for further analysis of the association of delirium with ICU stay for surgery, trauma, and neurology/neurosurgical cases.

In this study, the authors opted to use DSM-IV-TR criteria, which was still the standard adopted for diagnosis in the local setting at the time of study, despite the relatively recent release of DSM-V. It is worth noting that even now, there are controversies regarding DSM-V interpretation for delirium, compared to the well-established DSM-IV-TR. ${ }^{7,11}$

It is noted that this study lacked significant power in terms of the number of patients positive for delirium, and it is reflected in some of the results with non-statistically significant difference despite visible differences between groups that were impossible to be ignored especially in the clinical setting. For example, the $\sim 10$ years higher average age in the subjects positive for delirium, and the odds ratio of 3.457 for having delirium in sedated vs. non-sedated patients. A good clinician uses his/her clinical eye in intercepting medical problems as early as possible, and the authors agreed that these somewhat conflicting results are very good examples for this old adage in these days, where overabundance of medical technologies (and "good", "statistically significant" clinical evidence) may overwhelm the good old physical examination skills. In fact, evidence suggests that this has already been happening for quite some time. ${ }^{12,13}$

There is also the fact that patients were not tested for/officially documented of having cognitive impairment prior to the study, however based on the attending physicians' anamnesis (be it to the patient him/herself or to the relatives) and admitting diagnosis, we could safely rule out the possibility of any cognitive impairment as a confounding factor to the study. Patients with dementia, late-stage Parkinson's disease, and schizophrenia were also already excluded.

Another concern is the fact that there is no accepted universal standard in sedation protocols, whether it is as pre-medications for procedures (i.e. intubation), or as part of disease management (i.e. in the mechanically ventilated patients or patients with acute coronary syndrome). The possibility to study the relationships between different sedation protocols and prevalence or disease progression of delirium are open for future research projects, preferably with larger number of subjects, matched between delirium and non-delirium group.

Ideally, a multiple-repeated assessment for delirium should be conducted during the study period, however due to lack of manpower, such protocols were not able to be implemented in this study. 


\section{Research Article}

\section{Conclusions}

Delirium prevalence was $5.15 \%$ in adult Filipino patients admitted in the ICU of De Los Santos Medical Center. It was also associated with higher 14-days mortality and longer ICU stay. Based on this study, there was a lack of evidence to determine whether any particular medical / surgical / trauma / neurology / neurosurgical conditions are associated with higher risk to develop delirium.

\section{References}

1. American Psychiatric Association. DSM-IV-TR. Washington: Am Psychiatr Assoc; 2000.

2. American Psychiatric Association. Highlights of Changes from DSM-IV-TR to DSM-5. Am Psychiatr Assoc Washington, $\quad$.. $\quad$ [Internet]. $2013 ; 19 . \quad$ Available from: http://scholar.google.com/scholar?hl=en\&btnG=Search\&q=intitle:Highlights+of+Changes+from+DSM-IVTR+to+DSM-5\#0

3. Inouye SK, Van Dyck CH, Alessi C a., Balkin S, Siegal a. P, Horwitz RI. Clarifying confusion: The confusion assessment method: A new method for detection of delirium. Ann Intern Med. 1990;113(12):941-8.

4. Ely EW, Shintani A, Truman B, Speroff T, Gordon SM, Harrell FE, et al. Delirium as a predictor of mortality in mechanically ventilated patients in the intensive care unit. Jama [Internet]. 2004;291(14):1753-62. Available from: http://www.ncbi.nlm.nih.gov/pubmed/15082703

5. Cavallazzi R, Saad M, Marik PE. Delirium in the ICU: an overview. Ann Intensive Care [Internet]. 2012;2(1):49. Available from: http://www.ncbi.nlm.nih.gov/pubmed/23270646\%5Cnhttp://www.annalsofintensivecare.com/content/pdf/21105820-2-49.pdf

6. Bergeron N, Skrobik Y, Dubois MJ. Delirium in critically ill patients. Crit Care [Internet]. 2002;6(3):181-2. Available http://www.pubmedcentral.nih.gov/articlerender.fcgi?artid=137438\&tool=pmcentrez\&rendertype=abstract

7. Morandi A, Davis D, Taylor JK, Bellelli G, Olofsson B, Kreisel S, et al. Consensus and variations in opinions on delirium care: a survey of European delirium specialists. Int psychogeriatrics [Internet]. 2013 Dec [cited 2019 Feb 1];25(12):2067-75. Available from: http://www.ncbi.nlm.nih.gov/pubmed/23962713

8. Choi JG. Delirium in the intensive care unit. Korean J Anesthesiol [Internet]. 2013;65(3):195-202. Available from: 84885055263\&partnerID=40\&md5=e4e8a5f5d9112ef07349907e2846d403

9. Ely EW, Margolin R, Francis J, May L, Truman B, Dittus R, et al. Evaluation of delirium in critically ill patients: validation of the Confusion Assessment Method for the Intensive Care Unit (CAM-ICU). Crit Care Med. 2001;29:1370-9.

10. Pandharipande PP, Ely EW, Arora RC, Balas MC, Boustani MA, La Calle GH, et al. The intensive care delirium research agenda: a multinational, interprofessional perspective. Intensive Care Med [Internet]. 2017 Sep [cited 2019 Feb 1];43(9):1329-39. Available from: http://www.ncbi.nlm.nih.gov/pubmed/28612089

11. Meagher DJ, Morandi A, Inouye SK, Ely W, Adamis D, Maclullich AJ, et al. Concordance between DSM-IV and DSM-5 criteria for delirium diagnosis in a pooled database of 768 prospectively evaluated patients using the delirium rating scale-revised-98. BMC Med [Internet]. 2014;12:164. Available from: http://www.pubmedcentral.nih.gov/articlerender.fcgi?artid=4207319\&tool=pmcentrez\&rendertype=abstract

12. St Clair EW, Oddone EZ, Waugh RA, Corey GR, Feussner JR. Assessing housestaff diagnostic skills using a cardiology patient simulator. Ann Intern Med [Internet]. 1992 Nov 1 [cited 2019 Jan 31];117(9):751-6. Available from: http://www.ncbi.nlm.nih.gov/pubmed/1416578

13. Mangione S, Nieman LZ. Pulmonary Auscultatory Skills During Training in Internal Medicine and Family Practice. Am J Respir Crit Care Med [Internet]. 1999 Apr [cited 2019 Jan 31];159(4):1119-24. Available from: http://www.ncbi.nlm.nih.gov/pubmed/10194155 